\title{
Fluctuations of indicator and index microbes as indication of pollution over three years in the Plankenburg and Eerste Rivers, Western Cape, South Africa
}

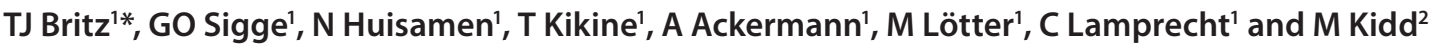 \\ 'Department of Food Science, University of Stellenbosch, Private Bag X1, Matieland 7602, South Africa \\ ${ }^{2}$ Centre for Statistical Consultation, Department of Statistics and Actuarial Sciences, University of Stellenbosch, \\ Private Bag X1, Matieland 7602, South Africa
}

\begin{abstract}
The Plankenburg and Eerste Rivers (Western Cape) have been reported to be contaminated with faecal coliforms. Water is drawn from both rivers for irrigation of fresh produce. The potential risk in the use of these rivers as irrigation sources was assessed by determining the fluctuations of 'indicator' and 'index' microbes over 3 years. Selected physico-chemical (water temperature, $\mathrm{pH}, \mathrm{COD}$, conductivity and alkalinity) and microbiological parameters, including coliforms, faecal coliforms, Escherichia coli and enterococci, as 'indicators' of faecal pollution, and Salmonella, Listeria and Staphylococcus, as 'index' of the presence of potential pathogens, were monitored.

No correlation was found between water temperature and COD $\left(r^{2}=0.0003\right)$, whereas for temperature and $\mathrm{pH}$ a significant trend $(p=0.0004)$, but low correlation $\left(r^{2}=0.108\right)$, was observed. With the exception of the faecal coliforms $(E$. coli), no significant trends and no correlations between temperature and the dependent variables were found. For the faecal coliforms there was a significant trend $(p=0.0289)$ with temperature but not a good correlation $\left(r^{2}=0.0434\right)$, but the impact of temperature over time was significant $(p=0.0047)$. This is important, when the World Health Organisation (WHO) and South African Department of Water Affairs (DWA) guidelines for faecal coliforms are applied, as it indicates that temperature does impact the faecal coliform numbers. The presence of indicator organisms did not only indicate unsanitary conditions, but also the presence of potential pathogens such as Staphylococcus, Klebsiella, Listeria and Salmonella. Based on these results the microbial quality of these rivers was found to be unacceptable and does not meet the WHO and DWA guidelines for safe irrigation. There was also a high risk of exposure to human pathogens when water from these rivers is used to irrigate produce that is consumed without further processing.
\end{abstract}

Keywords: Irrigation water, faecal pollution, indicator and index organisms, Plankenburg and Eerste Rivers

\section{INTRODUCTION}

Many South African rivers have been found to be unsuitable for irrigation of fresh produce, mainly because of the high levels of faecal contamination. In all the reports published to date (Barnes and Taylor, 2004; Germs et al., 2004; Griesel and Jagals, 2002; Olaniran et al., 2009; Paulse et al., 2009), it was found that faecal indicator organisms exceeded the South African Department of Water Affairs (DWA) and World Health Organisation (WHO) guideline limits of 1000 E. coli per $100 \mathrm{~m} \ell$ water for irrigation of fresh produce (DWAF, 1996; WHO, 1989).

The Plankenburg River has specifically been reported (Barnes and Taylor, 2004) to be highly contaminated with faecal coliforms, with counts of up to $12 \times 10^{6}$ E. coli per $100 \mathrm{~m} \ell$. From June 2004 to June 2005, faecal coliform counts as high as $3.6 \times 10^{6}$ E. coli per $100 \mathrm{~m} \ell$ were reported by Paulse et al. (2009) for the Plankenburg River. The Plankenburg and Eerste Rivers pass through the town of Stellenbosch and are both used upstream and downstream of the town for irrigation of fruit and vegetables during the summer months. This is mainly because the water from the river is readily available and easily accessible.

To whom all correspondence should be addressed.

iㅏㄴ +27 21 808-3578; fax: +27 21 808-3510;

e-mail: tjbritz@sun.ac.za

Received 20 July 2012; accepted in revised form 3 July 2013.
Fresh produce is recommended as part of a healthy diet to help prevent illnesses such as cardiovascular diseases. However, there is increasing evidence that consumption of fresh produce can be a major contributing factor to human gastrointestinal illness due to the potential for contamination with pathogenic microbes. Several studies have linked fresh produce foodborne outbreaks to polluted irrigation water as the major source of contamination (Pachepsky et al., 2011). According to Warriner and co-workers (Warriner et al., 2009) the presence and types of waterborne pathogens carried over to fresh produce vary greatly and can include a wide range of bacteria, protozoa and viruses. This sort of carryover has been reported to be high, especially in developing countries (Pachepsky et al., 2011). The scarcity of the water resources in South Africa, and the increasing evidence of pollution of the rivers, leaves little doubt that more attention needs to be paid to the types, fate and carryover potential of pathogens in waters that are utilised for irrigation of produce that will be consumed without any further processing steps.

On a national level, little is known about the level of pollution, and specifically faecal contamination, of South African rivers that are tapped for irrigation purposes. To get a clearer understanding of the problem, a national study was initiated in 2007 by the South African Water Research Commission (WRC, 2008) to determine the extent of the microbial contamination of South African rivers that are used for irrigation.

If DWA and WHO guidelines are applied to the data from previous short-term studies it must be concluded that the water 


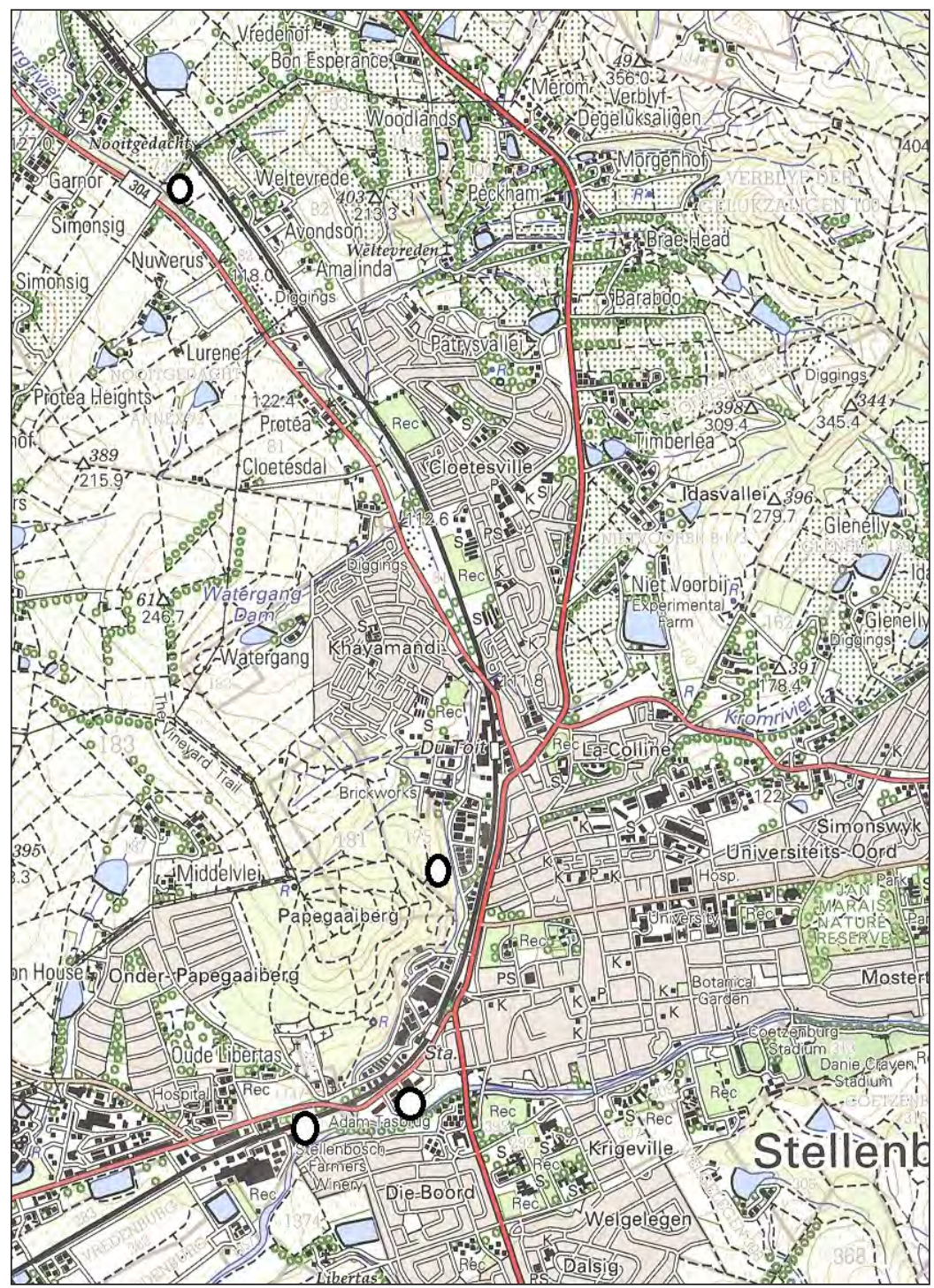

Figure 1

Sampling sites on the Plankenburg $(A=$ Plank- $O$ $B=$ Plank $-1 ; C=$ Plank-2) and Eerste Rivers $(D=$ Eerste- 1$)$ from these rivers is unsuitable for irrigation of produce, especially that which will be consumed with minimal processing. In order to establish a credible database of the long-term variations in the microbial quality of the Plankenburg and Eerste rivers, sites on these two economically important rivers were monitored over a longer period. This would also give a clear indication of the impact of different seasons on both the microbial types present and the levels as well as variations in chemical composition that could impact microbial loads.

The objective of this study was to assess pollution levels in the Plankenburg and Eerste rivers and the fluctuations of the indicator and index microbes over a 3 -year period.

\section{MATERIALS AND METHODS}

\section{Sampling sites}

The first sampling site on the Plankenburg River (Stellenbosch region of the Western Cape) is located just below the Kayamandi informal settlement (Fig. 1) and is referred as to the Plank-1 site. The second site (Plank-2) on this river is $1.5 \mathrm{~km}$ downstream from the first site and at the confluence point between the Plankenburg and Eerste Rivers. Local farmers use this section as an irrigation source point, to draw water for irrigation further down the river. The fresh produce irrigated includes grapes, citrus fruit, pears, lettuce and green beans. The third site (Eerste-1) was on the Eerste River (Jonkershoek River section) about $400 \mathrm{~m}$ before the Plankenburg River merges to form the main stem of the Eerste River. This river originates in the Jonkershoek Mountains, runs through small-scale farming areas where it is used for irrigation and aquaculture purposes and then passes through the Stellenbosch residential areas before it reaches the confluence point. A fourth sampling site (Plank-0) was selected about $5 \mathrm{~km}$ upstream from the Plank-1 site, specifically to assess the impact of an informal settlement and an industrial area on the water quality of the Plankenburg River. However, for large parts of each year, and especially during the dry summer months, this site had no flowing water and thus was not sampled with the same frequency as the other sites.

\section{Sampling frequency}

Both rivers were sampled once a month for 42 months (September 2007 to March 2011). The sampling was done on Mondays between 08:00 and 08:30, according to the SANS 5667-6 (SANS, 2006) guideline. The samples were transported on ice and analysed in duplicate. 


\section{Microbiological analysis}

The aerobic colony count (ACC) was used to give an indication of the size of the microbial population in the water. The aerobic and anaerobic spore formers were used to establish the presence of Bacillus and Clostridium strains. Total coliforms, faecal coliforms, E. coli and intestinal enterococci were used as indicator organisms for faecal contamination (Busta et al., 2003). The index organisms (Staphylococcus, Salmonella and Listeria) were used as indicators of the possible presence of related pathogens, i.e., Clostridium, Campylobacter, Giardia, Cryptosporidium, and other Gram-negative species (Busta et al., 2003).

\section{Aerobic colony count}

The aerobic colony counts were determined according to the SANS method 4833 (SANS, 2007). Results are reported as cfu $\cdot \ell^{-1}$ of sample.

\section{Aerobic and anaerobic spore formers}

The spore formers were determined using the method of Austin (1998) by preparing a dilution series of the sampled water in PSS (physiological salt solution) and placing them in a $75^{\circ} \mathrm{C}$ water bath for $20 \mathrm{~min}$ (Austin, 1998). Trypticase soy agar (Merck) plates were both aerobically and anaerobically incubated at $35^{\circ} \mathrm{C}$ for $48 \mathrm{~h}$. Data was reported as cfu.m $\ell^{-1}$ of sample (Merck, 2007).

\section{Coagulase-positive staphylococci}

Staphylococci were enumerated according to the SANS 6888-1 method (SANS, 2000) using Baird-Parker agar (Merck). Typical colonies were identified as black with a clear zone and the data reported as cfu-m $\ell^{-1}$ of sample (Merck, 2007), with atypical colonies being dark brown, greyish or black colonies. The identities of typical colonies were confirmed using the API Staph test kit (Biomerieux, South Africa).

\section{Salmonella}

The pre-enrichment, enrichment and confirmation steps required for the detection of Salmonella species were conducted as described in the SANS 6579 method (SANS, 2003). Typical colonies were identified as black and the presence of Salmonella reported as either present or absent (Merck, 2007). Typical colonies were confirmed on Salmonella chromogenic medium (Oxoid, Hampshire, England).

\section{Listeria}

The detection of Listeria monocytogenes was according to SANS method 11290-1 (SANS, 2001), which requires both a primary and secondary enrichment step and streaking onto Oxford agar (Merck) and Palcam agar (Merck) plates. Typical colonies were identified as grey-green with a black zone, and the presence of Listeria reported as either present or absent (Merck, 2007). Colonies were further characterised and identified using the specific API kit (Biomerieux, South Africa).

\section{Intestinal enterococci}

A $0.45 \mu \mathrm{m}$ membrane filter was used to filter $100 \mathrm{~m} \ell$ of sample according to the SANS 7899-2 method (SANS, 2004), the filter placed on Slanetz \& Bartley plates (Merck) and incubated at $35^{\circ} \mathrm{C}$ for $44 \mathrm{~h}$. The filter was then placed on Bile Esculin Azide plates and incubated at $44^{\circ} \mathrm{C}$ for $2 \mathrm{~h}$. Typical colonies were black and the data reported as cfu.100 $\mathrm{m}^{-1}$ of sample (Merck, 2007). Colonies were identified using the specific API kit (Biomerieux, South Africa).

\section{Coliforms, faecal coliforms and E. coli}

Detection in river water was done using the multiple tube fermentation (MTF) method (Cristensen et al., 2002) and Standard Methods (APHA, 1998). Numbers were determined using the Most Probable Number (MPN) tables. For confirmation of the presence of $E$. coli, positive faecal coliform tubes were streaked on Levine eosin methylene blue (L-EMB) plates (Merck). Colonies that had a metallic green sheen were considered positive for E. coli (Merck, 2007). Colonies were identified using the API 20 E kit (Biomerieux, South Africa). The dilution factor of the positive faecal coliform broth tubes that resulted in typical colonies was used to determine the E. coli count from the MPN tables (APHA, 1998). The MTF results were expressed as coliforms, faecal coliforms and E. coli MPN $100 \mathrm{~m}^{-1}$.

\section{Microbial diversity in water samples from the different sites}

Results obtained during the study indicated that various hurdles, such as enrichment steps, incubation temperatures and selective differential media, which form part of the standard identification methods for the detection of specific organisms, sometimes failed to exclude unwanted organisms. As a result, many non-typical colonies were obtained on the final evaluation medium that did not resemble the typical colony characteristics recommended in the standard methods.

All colonies obtained from the various selective media, whether they resembled typical colony characteristics or not, were subjected to further testing to establish their identity. Characteristics of purified isolates were subjected to Gramstaining, cell and colony morphology, catalase and oxidase and characterisation with specific API test kits (Biomerieux). These included the API Staph; API 20 Strep; API 20E and NE; API 50 $\mathrm{CHB}$ and the API Listeria kits, each performed according to the specific API instruction manual (BioMerieux, F-69280 Marcy l'Etoile, France). Only API results with a $\geq 95 \%$ identification (classified as 'good', 'very good' and 'excellent') were regarded as positive identifications.

\section{Physico-chemical analysis}

The parameters that were monitored according to Standard Methods (APHA, 1998) included water temperature and $\mathrm{pH}$ at site, alkalinity, conductivity and chemical oxygen demand (COD). Conductivity $\left(\mathrm{mS} \cdot \mathrm{m}^{-1}\right)$ was determined using a Hanna Instruments (HI8733) conductivity meter. A DR2000 spectrophotometer (Hach Co. Loveland, CO) was used to colourimetrically determine the COD and data expressed as $\mathrm{mg} \mathrm{O}_{2} \cdot \ell^{-1}$.

\section{Statistical analysis}

Relationship between temperature and other parameters was investigated by doing regressions with temperature as independent predictor and ACC, COD, pH, faecal coliforms (E. coli) and coliforms as dependent predictor variables. The resulting regression coefficients quantified the type of association between the predictor and respective dependent variable. As this was a time-series data set, the Durbin-Watson (d) test was done to determine the serial correlation for all the above parameters. This value must be near 2, which would then indicate that there is no serial correlation. Additionally a TSCREG (time-series cross-sectional regression) was done. Results are interpreted as a normal regression. A $p$ value of $<0.05$ was considered statistically significant. 
TABLE 1

Physico-chemical data for the three river sites (Plank-1 and 2 and Eerste-1) for the period September 2007 to March 2011 ( $n=20-42$ samples per site)

\begin{tabular}{|l|c|c|c|c|c|c|c|c|c|c|}
\hline \multirow{2}{*}{ Site } & \multicolumn{2}{|c|}{$\begin{array}{c}\text { Temperature } \\
{ }^{\circ} \mathbf{C}\end{array}$} & \multicolumn{2}{|c|}{$\mathbf{p H}$} & \multicolumn{2}{c|}{$\begin{array}{c}\text { Alkalinity } \\
\mathbf{m g} \cdot \ell^{-1}\end{array}$} & \multicolumn{2}{c|}{$\begin{array}{c}\text { Conductivity } \\
\mathbf{m S} \cdot \mathbf{m}^{-1}\end{array}$} & \multicolumn{2}{c|}{$\begin{array}{c}\text { COD } \\
\mathbf{m g} \cdot \ell^{-1}\end{array}$} \\
\cline { 2 - 13 } & Min & Max & Min & Max & Min & Max & Min & Max & Min & Max \\
\hline Plank-1 & 10.2 & 20.8 & 5.97 & 7.20 & 14 & 1125 & 3 & 62 & 0 & 69 \\
\hline Plank-2 & 9.9 & 21.8 & 5.78 & 7.24 & 25 & 1000 & 1 & 89 & 0 & 421 \\
\hline Eerste-1 & 10.1 & 21.8 & 5.63 & 7.05 & 13 & 250 & 8 & 87 & 0 & 296 \\
\hline
\end{tabular}

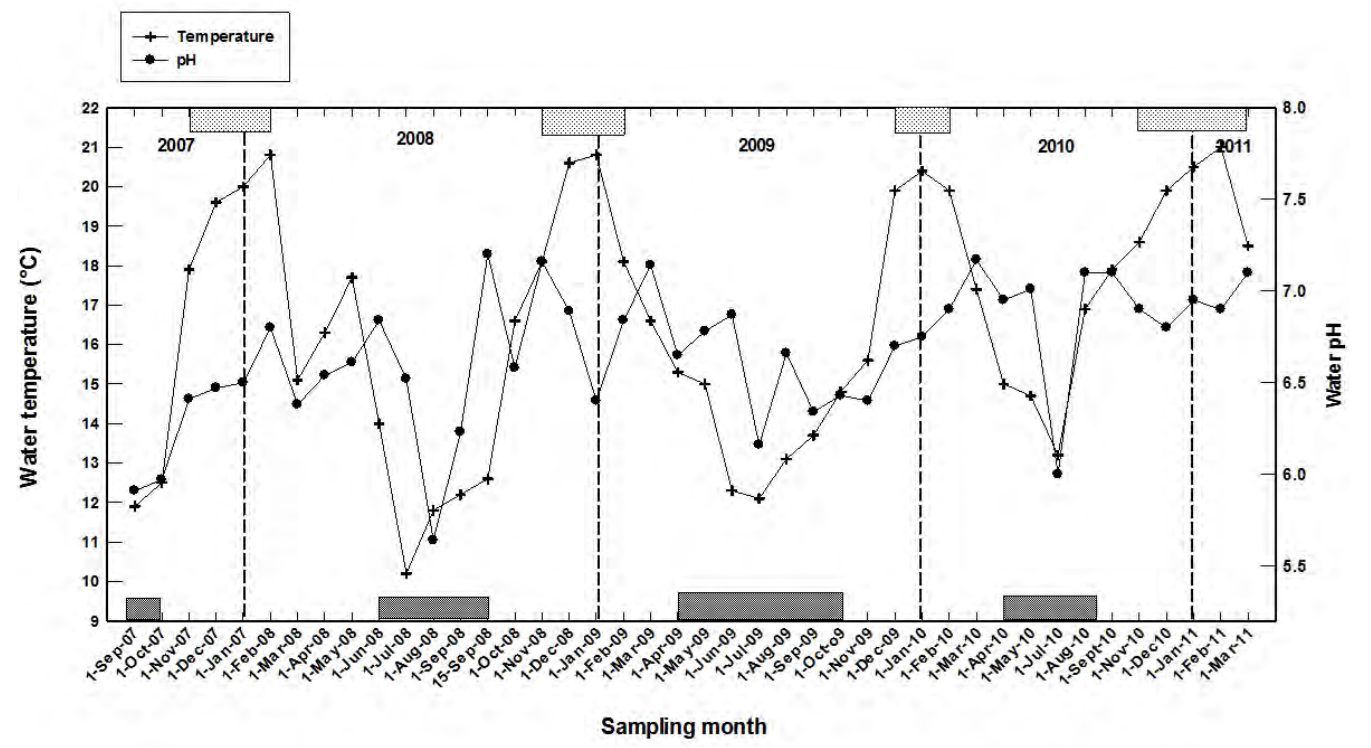

Figure 2

Temperature and $\mathrm{pH}$ values of the river water from the Plank-1, Plank-2 and Eerste-1 sites. Values are averages of the temperatures and pH from all three sites. Temperatures below $15^{\circ} \mathrm{C}$ were taken as winter values (darker blocks at bottom of graph) and those above $18^{\circ} \mathrm{C}$ as summer values (dotted blocks at top of graph).

\section{RESULTS AND DISCUSSION}

\section{Physico-chemical analysis}

The environmental and chemical data obtained during the research period (September 2007 - March 2011) for each of the three sites, are summarised in Table 1 . The temperature data for water from the three sites were similar and ranged from $9.9^{\circ} \mathrm{C}$ to $21.8^{\circ} \mathrm{C}$ with the lower values found during the colder winter months $\left(<15^{\circ} \mathrm{C}\right.$ : May to October $)$ and the highest in the summer months $\left(>18^{\circ} \mathrm{C}\right.$ : December to February), as indicated in Fig. 2. The $\mathrm{pH}$ ranged from 5.63 to 7.24 with values mostly above 6.0, on average. These values are within DWA's Target Water Quality Range (TWQR) of pH 6.0 to 9.0 (DWAF, 1996). Conductivity ranged from 2 to $11 \mathrm{mS} \cdot \mathrm{m}^{-1}$ and is within DWA's TWQR of 0 to $70 \mathrm{mS} \cdot \mathrm{m}^{-1}$ (DWAF, 1996). Alkalinity ranged from 13 to $1125 \mathrm{~m}^{-1} \mathrm{CaCO}_{3}$ and COD from zero to $296 \mathrm{mg} \cdot \ell^{-1}$. The higher alkalinity values were mostly found at the Plank-1 site where values of above 100 were regularly recorded. Since this site is just below the Kayamandi informal settlement and the Plankenbrug industrial area the fluctuations could be caused by nutrient cycling or effluent discharges. Overall it was concluded that according to physico-chemical DWA guidelines the Plankenburg and Eerste River water will have no adverse effect on crop yield and, based on this, the water can be used for irrigation of fresh produce.

\section{Microbiological parameters}

\section{Index organisms}

The ACC results for the three sites are presented in Fig. 3 and ranged from $<\log 1.69$ to $>\log 6.88 \mathrm{cfu} \cdot \mathrm{ml}^{-1}$ of water. This wide variation in ACC values has also been previously reported for the Plankenburg River (Barnes, 2003; Paulse et al., 2009) and for the Baynespruit River in KwaZulu-Natal (Gemmell and Schmidt, 2012). On average the Eerste-1 site gave lower counts than was found for the other two sites, which gave similar counts to each other. It is interesting to note that visually the ACC counts during the winter months did not appear to be lower on account of the lower temperatures. The ACC data is generally taken as representative of the total microbial content including spoilage microorganism (Sela and Fallik, 2009). However, DWA guidelines only give values for the heterotrophic bacterial counts, recommending a value of less than log $2.0 \mathrm{cfu}$ per $\mathrm{m} \ell$ for safe domestic use.

The highest count for the aerobic spore formers was log $4.35 \mathrm{cfu} \cdot \mathrm{m}^{-1}$, recorded in December 2009 for the Plank-1 site. This is a clear indication that aerobic spore formers, such as members of the Bacillus genus, were present at times in the water. The count for the anaerobic spore formers ranged from $\log 1.71$ to $\log 4.08 \mathrm{cfu} \cdot \mathrm{m}^{-1}$ and it was concluded that anaerobic spore formers of the Clostridium genus were present in the water. Although not all endospore formers are human pathogens, both B. cereus and C. botulinum are important foodborne pathogens (Harris et al., 2003; Kim et al., 2006; Kim et al., 2010), and if irrigation water contained these it could lead to colonisation and formation of biofilms on the surface of fresh produce (Niemera and Cooke, 2010 ). This could possibly result in disease outbreaks or faster spoilage of the fresh produce and even blowing of improperly canned vegetables.

The highest count for staphylococci was $\log 2.63 \mathrm{cfu} \cdot \mathrm{m}^{-1}$, recorded in April 2010. The percentage of positive samples found in the water from the three sites is given in Table 2. Typical colonies on the Baird-Parker plates were identified 


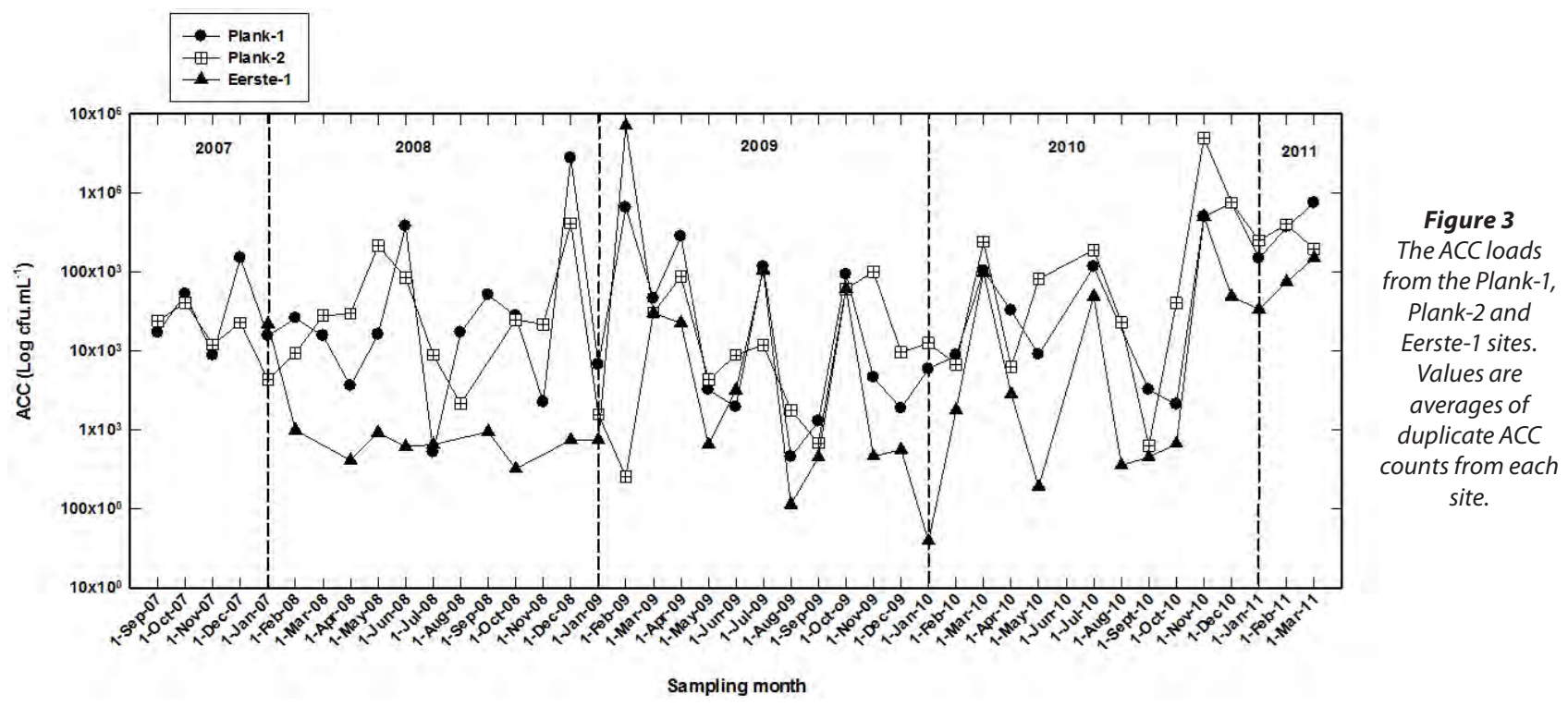

\begin{tabular}{|l|c|c|c|c|c|}
\hline \multicolumn{6}{|c|}{ TABLE 2} \\
Percentage of samples positive for faecal indicator \\
and index organisms \\
\hline \% of samples positive for indicator and index organisms \\
\hline Site & E. coli & $\begin{array}{c}\text { Staphylo- } \\
\text { coccus }\end{array}$ & $\begin{array}{c}\text { Salmo- } \\
\text { nella } \\
\text { spp. }\end{array}$ & $\begin{array}{c}\text { Listeria } \\
\text { spp. }\end{array}$ & $\begin{array}{c}\text { Intestinal } \\
\text { enterococci }\end{array}$ \\
\hline Plank-0 & 10 & 0 & 0 & 0 & 5 \\
\hline Plank-1 & 100 & 44 & 61 & 56 & 79 \\
\hline Plank-2 & 100 & 44 & 54 & 51 & 74 \\
\hline Eerste-1 & 100 & 15 & 67 & 39 & 78 \\
\hline
\end{tabular}

as round black colonies with a clear zone (Merck, 2007). The data could also be an indication that enterotoxin-producing Staphylococcus aureus strains that can cause food poisoning may be present in the water (Cha et al., 2006).

The intestinal enterococci count ranged from log 1.49 to log $3.24 \mathrm{cfu} \cdot \mathrm{m} \ell^{-1}$ and for all three sites $>74 \%$ of samples were positive for intestinal enterococci (Table 2). Enterococcus faecalis strains are generally used as indicators of faecal contamination (Agudelo et al., 2010) and thus the presence of intestinal enterococci was taken as an additional indicator of faecal contamination of the water from these rivers.

Salmonella and Listeria were present in the water of $>50 \%$ and $>39 \%$ of the Plank- 1 and 2 and Eerste- 1 samples (Table 2 ), respectively, over the 42 -month sampling period. Both pathogens are considered as food safety hazards (Mead et al., 1999). The presence of Salmonella in the water also confirms faecal contamination as a source of pollution, as this pathogen generally occurs in faecal matter of warm-blooded animals or infected humans (Renter et al., 2006). The high Salmonella incidence could pose a health threat since some residences in the surrounding areas draw water from the Plankenburg and Eerste rivers for gardening and household purposes. Therefore, contact with the water could lead to a serious health hazard.

The high incidence of index organisms suggests the possible survival and build-up of related foodborne pathogens resulting from continuous faecal contamination of the river. Thus, regular monitoring of river systems is critical in preventing possible disease outbreaks since members of the genus Salmonella are food pathogens that have been associated with many disease outbreaks (Newell et al., 2010). This is a clear indication that the survival of pathogens is possible in flowing streams. Therefore continuous faecal contamination of the river water may lead to a possible build-up of related disease-causing foodborne pathogens in the water.

\section{Faecal indicators}

The coliform counts for all three sites shown in Fig. 4 ranged from $\log 2.518$ to $6.845 \mathrm{MPN} \cdot 100 \mathrm{~m}^{-1}$ and the faecal coliform (E. coli) counts (Fig. 5) ranged from zero to log 6.845 MPN.100 $\mathrm{m}^{-1}$. At the start of the study it was expected that seasonal changes would impact the microbial loads, with much lower numbers present found during the colder and rainy winter months. However, it was concluded from the graphs that there is no relationship between the coliform and faecal coliform (E. coli) counts and the water temperature or the water $\mathrm{pH}$. The data show that higher microbial counts $(>\log 5)$ were found both in the summer and winter months. It could be that the higher flow rates associated with heavy rainfall during the winter months could have led to higher coliform counts because of increased run-off from the informal settlement or re-suspension of bacteria from the river sediments (Dukta and Kwan, 1980). Ackermann (2010) reported a high faecal coliform count of $\log 5.204 \mathrm{MPN} \cdot 100 \mathrm{~m}^{-1}$ for the Plank-1 site in early August 2008 , following heavy rainfall at the end of July 2008. Therefore rainfall and river flow rates may impact the faecal coliform load through dilution and re-suspension, resulting in the large count variation profiles shown in Fig. 4.

When the results for the Plank-1 site are compared with those from the Plank-2 site, which is about $1.5 \mathrm{~km}$ downstream, no direct relationship is visible. One would have expected that the Plank-2 loads would have been much lower due to dilution, bacterial decay or even settling between Plank-1 and Plank-2. It must also be taken into consideration that coliforms have been shown to survive and possibly multiply for a period of several days in a flowing stream (Dukta and Kwan, 1980). It is also possible that there is another contamination source between the two sites. However, the data do suggest that there is a continuous source of contamination from the informal settlement and possibly from the industrial area.

The results for Eerste-1 (Figs. 4 and 5) showed lower coliform and faecal coliform (E. coli) loads than that found for the two Plankenburg sites. The coliform and faecal coliform counts varied from a low $\log 2.361$ to $4.897 \mathrm{MPN} \cdot 100 \mathrm{~m}^{-1}$ water. The 


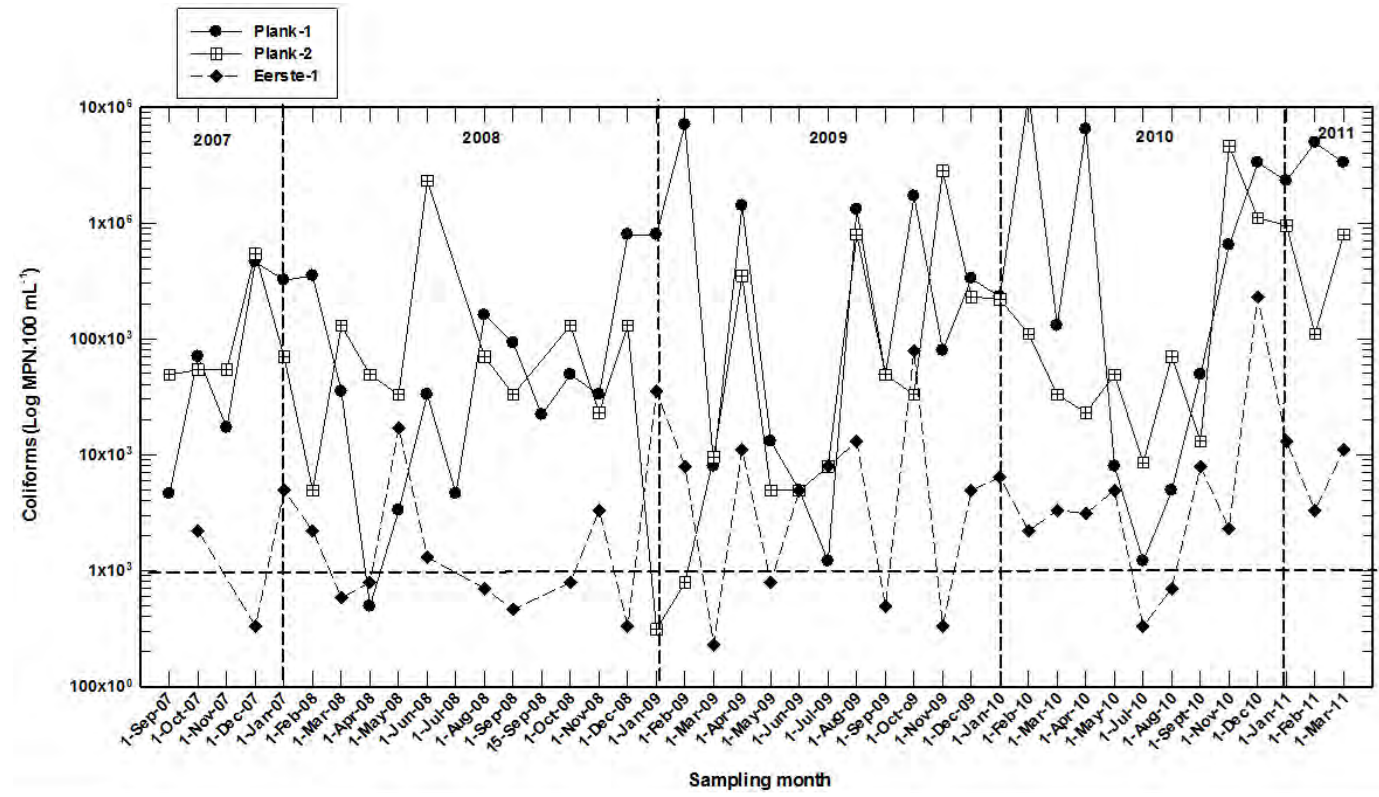

Figure 4

Coliform loads in samples from the Plank-1, Plank-2 and Eerste-1 sites.

Values are averages of duplicate counts from each site. The bold dotted line represents the DWA and $W H O$ guidelines $(<1000$ E. coli. $100 \mathrm{ml}^{-1}$ water).

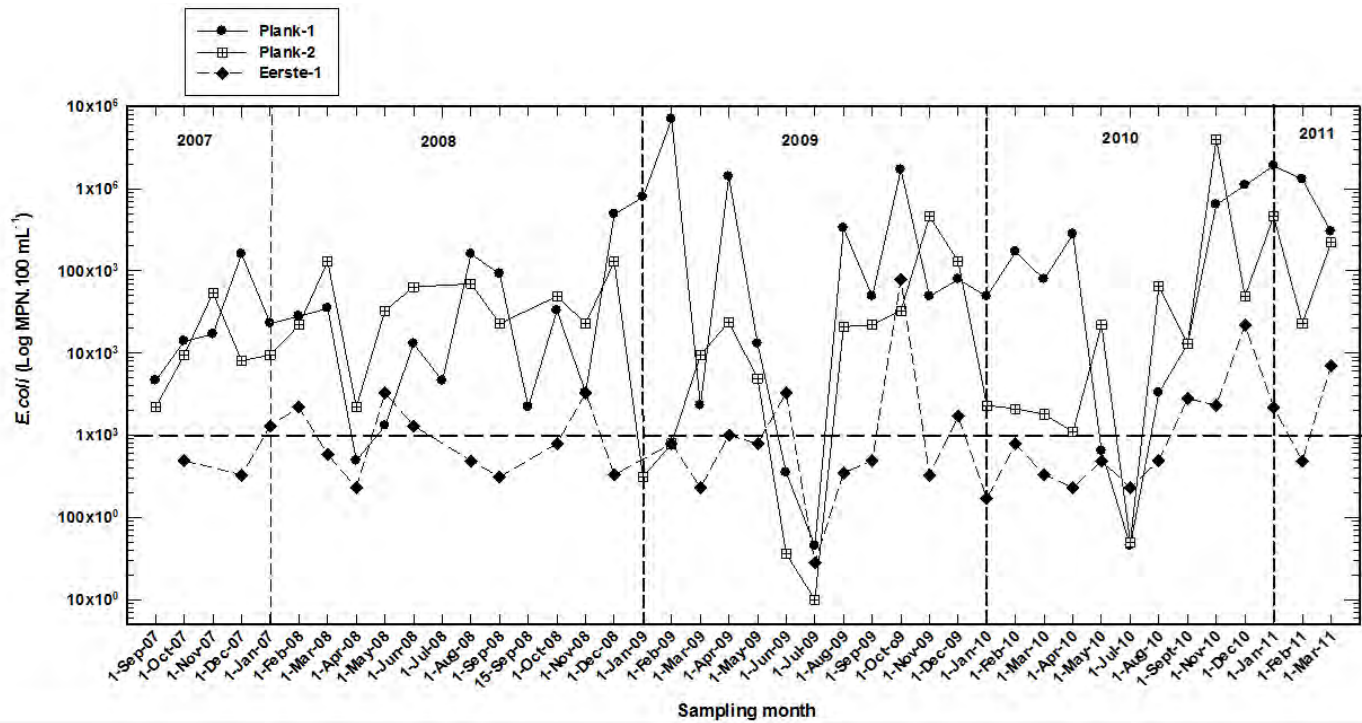

Figure 5

The E. coli loads at the Plank-1, Plank-2 and Eerste-1 sites.

Values are averages of duplicate counts from each site. The bold dotted line represents the DWA and WHO guidelines (<1 000 E. coli. $100 \mathrm{~m}^{-1}$ water).

water from this site does not pass an informal settlement or a large industrial area but does pass through a farming area and then through the town of Stellenbosch. Although the coliform counts were lower in the Eerste-1 samples compared to those in the Plank-1 and 2 samples, in a number of cases (35\%) they still exceeded the DWA and WHO guidelines of $<1000$ faecal coliform $\cdot 100 \mathrm{~m}^{-1}$ for the safe use of water for irrigation. It was therefore concluded that the Eerste River could still pose a health and food safety hazard if used for irrigation of fresh produce intended to be consumed raw.

The faecal coliforms dilutions were all confirmed as containing typical E. coli (Table 1) on L-EMB plates (Merck, 2007). Therefore the maximum $E$. coli count was also considered to be $\log 6.845 \mathrm{MPN} \cdot 100 \mathrm{~m}^{-1}$ of water (Fig. 5). When applying the DWA and WHO guideline of $<1000$ faecal coliform 100 $\mathrm{m} \ell$, irrigation water, both rivers can be considered as unsuitable for irrigation of fresh produce intended to be consumed raw (DWAF, 1996; WHO, 1989). The high E. coli counts also suggest high faecal contamination of the water at both of the Plankenburg sampling sites (Plank-1 and 2), as the presence E. coli is indicative of animal or human faecal pollution sources
(Busta et al., 2003). This is consistent with the results of previous studies (Barnes and Taylor, 2004; Lötter, 2010; Paulse et al., 2009). Since the Plank-0 site showed no or very low E. coli numbers it was concluded that the nearby informal settlement and/ or local industries may possibly have been the main sources of the pollution.

When considering this study's maximum faecal coliform loads, there appears to have been a general decrease in the faecal contamination of the Plankenburg River over time, as Barnes and Taylor (2004) reported a maximum E. coli count of $\log 7.0792 \mathrm{MPN} \cdot 100 \mathrm{~m}^{-1}$ for the Plank-1 site in 2000. Similarly, for the year 2005, Paulse et al. (2009) reported an E. coli count of $\log 6.5563 \mathrm{MPN} \cdot 100 \mathrm{~m}^{-1}$ at the same sampling site, and in 2007 Lötter (2010) reported a maximum E. coli count in February 2009 of $\log 6.845 \mathrm{MPN} \cdot 100 \mathrm{~m}^{-1}$ for the same site.

This general decrease in $E$. coli could be because of dilution factors, lack of suitable carbon sources, accelerated decay rates, biofilm formation or even the settling and retention of organisms in the sediment, as has been shown to be possible in flowing streams (Dukta and Kwan, 1980). Furthermore, the decrease in E. coli could also be due to a decrease in 


\begin{tabular}{|l|l|c|c|c|c|c|}
\hline \multicolumn{7}{|c|}{$\begin{array}{l}\text { TABLE } 3 \\
\text { Regression summary for temperature as independent predictor and coliforms, faecal } \\
\text { coliforms (E. coli), ACC, pH and COD as the dependent variables }\end{array}$} \\
\hline \multirow{2}{*}{ Test } & Coliforms & $\begin{array}{c}\text { Faecal } \\
\text { coliforms }\end{array}$ & ACC & pH & COD \\
\hline \multirow{2}{*}{ Regression } & $r^{2}$ & 0.0312 & 0.0434 & 0.0238 & 0.1085 & 0.0003 \\
\cline { 2 - 7 } & $p$-value & 0.0644 & 0.0289 & 0.1072 & 0.0004 & 0.8481 \\
\hline \multirow{2}{*}{$\begin{array}{l}\text { Durbin- } \\
\text { Watson }\end{array}$} & $\mathrm{D}$ & 1.1770 & 1.0073 & 1.3456 & 1.5346 & 2.0937 \\
\cline { 2 - 7 } & Serial corr. & 0.4102 & 0.4962 & 0.3257 & 0.2223 & -0.0479 \\
\hline \multirow{2}{*}{ TSCSREG } & $r^{2}$ & 0.0548 & 0.0715 & 0.0403 & 0.0399 & 0.0004 \\
\cline { 2 - 7 } & $p$-value & 0.0139 & 0.0047 & 0.1188 & 0.0365 & 0.8429 \\
\hline
\end{tabular}

contamination from the nearby informal settlement. Though the overall counts for the period September 2007 to March 2011, as determined in this study, are lower than that reported in previous studies (Barnes and Taylor, 2004; Paulse et al., 2009), when considering the DWA and WHO guidelines the water should not be used for irrigation of fresh produce. The presence of $E$. coli in the water could pose a health and food safety hazard if the water is used to irrigate fresh produce intended to be consumed raw, since pathogens are known to have the ability to attach to plant tissue (Solomon and Sharma, 2009).

\section{Statistical correlations}

The regression summary is given in Table 3. For the environmental parameters there was no correlation between water temperature and COD $\left(r^{2}=0.0003\right)$ and for the $\mathrm{pH}$ a significant trend $(p=0.0004)$ but only a low correlation $\left(r^{2}=0.108\right)$ was found. For the microbiological parameters, with the exception of the faecal coliforms (E. coli), no significant trends and no correlations between temperature and the dependent variables were found. For the faecal coliforms there was a significant trend $(p=0.0289)$ but not a good correlation $\left(r^{2}=0.0434\right)$.

As the results for the rivers formed a time-series data set, the Durbin-Watson (d) test was done to determine the serial correlation for all the above parameters. Values below 2 indicate that there is a serial correlation with one exception (COD). Therefore a time series cross-sectional regression (TSCSREG) was done. All of the variables (Table 3 ) showed a weak correlation but the impact of temperature over time on the faecal coliforms (E. coli) was significant $(p=0.0047)$. This is an important finding, especially when the WHO and DWA guidelines for faecal coliforms (E. coli) are applied, as it indicates that temperature, even at temperatures much lower than the $37^{\circ} \mathrm{C}$ required for optimum growth, does impact on the count.

\section{Microbial diversity in water samples from the different sites}

Table 4 gives a list of other microbes isolated and identified from the three main sampling sites during the sampling period. The lower pollution level of site Plank- 0 in comparison to the extremely polluted Plank-1 and 2 sites could again be seen, with several potential pathogenic organisms detected at Plank-1 and 2, but absent at Plank-0. Fewer organisms isolated from site Eerste-1 also suggested a better water quality at this site in contrast to the poor water quality of the Plank-1 and 2 sites. Most importantly, however, the isolates did not only include faecal indicators such as faecal coliforms, E. coli and enterococci, but, among the index organisms, also potential pathogens such as Klebsiella pneumoniae, Listeria monocytogenes, Salmonella and Staphylococcus aureus. The presence of such index organisms in river water is disturbing, as most, if not all, have been implicated in both waterborne and foodborne outbreaks in the past (Wilkes et al., 2009). It can therefore again be concluded that the water quality from these sites is of unacceptable microbiological quality and could potentially present a threat to the health of any person or animal that is exposed to it.

While it was not within the scope of this study to detect and identify all of the microorganisms present in the river water samples, it can be seen from the results that microorganisms - and potential pathogens - other than those that were tested for, were present. This highlights the importance and function of indicator and index organisms, as the levels that they are present in reflect the state of contamination of river water, without it being necessary to test the water for each microbial genus or species.

\section{CONCLUSION}

The high aerobic colony, total coliform and faecal coliform counts for both the Plankenburg and Eerste River sites indicate a continuously high level of microbial contamination. The presence of the indicator E. coli in all of the water samples evaluated, and the presence of intestinal enterococci, confirms the type of pollution as being faecal. It was thus concluded that the water from these two rivers does not meet the WHO and DWA guidelines for safe irrigation (DWAF, 1996; WHO, 1989).

The much lower pollution level of the Plank-0 site in comparison to the extremely polluted Plank-1 and 2 sites is striking. As Plank-1 and 2 are downstream of an informal settlement and an industrial area, and since the upstream Plank-0 site showed no or very low $E$. coli numbers and no potential pathogenic organisms, it was concluded that the nearby informal settlement and/or local industries could be the main sources of the pollution.

The high incidence of the index organisms (Salmonella, Staphylococcus and Listeria) confirms the presence of other related enteric pathogens. The enumeration of aerobic and anaerobic endospore formers also suggests the presence of other known foodborne pathogens and general spoilage organisms from the genera Bacillus and Clostridium.

The data from this study clearly shows that the two sites on the Plankenburg River were more polluted than the site on the Eerste River. Intestinal enterococci loads were also higher for these two sites than for the Eerste River site. It was also interesting to note that Staphylococcus numbers were much lower for the Eerste River in comparison to the numbers present in the Plankenburg sites. Therefore there is a possibility that enteric 
TABLE 4

Microbes identified during the sampling period. The identification percentage was based on the \%ID value from the API database as per the specific API kit used.

\begin{tabular}{|l|c|c|c|c|c|}
\hline Genus/species & ID\% & Plank-0 & Plank-1 & Plank-2 & Eerste-1 \\
\hline Aeromonas sp. & 80 & - & + & + & + \\
\hline Bacillus sp. & $50-80$ & + & + & + & + \\
\hline Citrobacter sp. & $<50$ & - & + & + & + \\
\hline C. freundii & 96 & + & + & + & + \\
\hline Clostridium sp. & $50-60$ & + & + & + & + \\
\hline Escherichia sp. & $70-80$ & - & + & + & + \\
\hline E. coli & $98-99$ & + & + & + & + \\
\hline Enterobacter sp. & $<50$ & + & + & + & + \\
\hline E. aerogenes & 91 & - & + & + & + \\
\hline Enterococcus sp & 50 & + & + & + & + \\
\hline Klebsiella sp. & $<50$ & - & + & + & + \\
\hline K. oxytoca & 98 & - & + & + & + \\
\hline K. pneumoniae & $90-95$ & - & + & + & + \\
\hline Kluyvera sp. & $<50$ & + & + & + & + \\
\hline Listeria innocua & $>80$ & - & - & - & + \\
\hline L. ivanovii & 98 & - & + & + & - \\
\hline L. grayi & 95 & - & + & + & + \\
\hline L. monocytogenes & 98 & - & + & + & - \\
\hline Morganella sp. & $<50$ & - & + & + & + \\
\hline Proteus mirabilis & 98 & - & + & - & - \\
\hline P. vulgaris & 90 & + & + & + & + \\
\hline Pantoea sp. & $50-60$ & - & + & + & + \\
\hline Salmonella sp. & 50 & - & + & + & + \\
\hline S. enteritidis & 74 & - & + & + & - \\
\hline S. typhimurium & $80-90$ & - & + & + & - \\
\hline S. odorifera & $50-60$ & - & + & + & + \\
\hline S. marcescens & 95 & + & + & + & + \\
\hline Shigella sp. & $50-60$ & - & + & + & - \\
\hline S. sonnei & 95 & - & + & + & - \\
\hline Staph. aureus & 99 & - & + & + & + \\
\hline Staph. xylosus & $90-98$ & - & + & + & - \\
\hline & & & & \\
\hline & & + & + \\
\hline
\end{tabular}

$(-)=$ not detected $;(+)=$ present

pathogens that may cause disease outbreaks can be transferred to crops through irrigation.

The data showed a lot of variation which suggests that there is a possibility that the water is not always highly contaminated. This also means that there is a possibility that during a particular month the river may have low E. coli loads that are within the guidelines, making the river water suitable for irrigation of fresh produce intended to be consumed raw. The question of whether temperature has a direct impact on the microbial counts has always been of interest. Temperature is a very important variable, especially for the setting of guidelines, because a particular set of monitoring data may represent an overestimate or underestimate of the actual contamination level, due to the impact of temperature on the survival and growth of microbial organisms.

The change in weather conditions, which in turn affects the water temperature, was at the beginning of this study suspected to be the main cause of the variation in microbial loads. However, this was not found to be the case, as the regression analysis showed no correlation $(p<0.05)$ between the microbial (total coliforms and E. coli) and physico-chemical variables (water temperature and $\mathrm{pH}$ ). However, the TSCREG showed a weak correlation, and the serial impact of temperature over time on the faecal coliforms and specifically the E. coli was shown to be significant $(p=0.047)$. It was thus concluded that temperature, as measured during this study, could have had an impact on the faecal organisms. However, no experiments were done to show what the survival and growth of the faecal microbes would be at different temperatures. Therefore growth kinetics studies should be done to extensively investigate the impact of temperature and other physico-chemical variables on the survival and growth of faecal organisms in rivers. Another important aspect that needs to be addressed is the extent to which carry-over of contaminants can occur when polluted irrigation water is applied to fresh produce.

\section{ACKNOWLEDGEMENTS}

This study was part of an on-going solicited research project (K5/1773) funded by the Water Research Commission and co-funded with the Department of Agriculture, Forestry and Fisheries. Financial support provided by the National Research Foundation (IFR2008112100010) in the form of postgraduate bursaries is gratefully acknowledged. The authors would also like to thank Dr Gerhard Backeberg of the Water Research Commission for his valuable support, as well as the many farmers who allowed sampling on their premises.

\section{REFERENCES}

ACKERMANN A (2010) Assessment of microbial loads of the Plankenburg and Berg Rivers and the survival of Escherichia coli on raw vegetables under laboratory conditions. MSc Food Science thesis, Stellenbosch University, Stellenbosch, South Africa.

AGUDELO RM, CODONY F, ADRADOS B, FITTIPALDI M, PENUELA G and MORATO J (2010) Monitoring bacterial faecal contamination in waters using multiplex real-time PCR assay for Bacteroides spp. and faecal enterococci. Water SA 36 (1) 127-132.

APHA (1998) Standard Methods for the Examination of Water and Wastewater $\left(20^{\text {th }}\right.$ edn.) American Public Health Association, Washington.

AUSTIN JW (1998) Method MFLP-44: Determination of aerobic and anaerobic endosporeformers. Laboratory Procedure, Health Protection Branch, Ottawa. PolyScience Publications (Health Canada), Quebec.

BARNES JM (2003) The impact of water pollution from formal and informal urban developments along the Plankenbrug River on water quality and health risk. PhD dissertation, University of Stellenbosch, Stellenbosch.

BARNES JM and TAYLOR MB (2004) Health risks assessment in connection with the use of microbiologically contaminated source waters for irrigation. WRC Report No. 1226/1/04. Water Research Commission, Pretoria.

BUSTA FF, SUSLOW TV, PARISH ME, BEUCHAT L, FARBER JN, GARRETT EH and HARRIS LJ (2003) The use of indicators and surrogate microorganisms for the evaluation of pathogens in fresh and fresh-cut produce. Comp. Rev. Food Sci. Food Saf. 2 179-185.

CHA JO, LEE JK, JUNG YH, YOO JI, PARK YK, KIM BS and LEE YS (2006) Molecular analysis of Staphylococcus aureus isolates associated with staphylococcal food poisoning in South Korea. J. Appl. Microbiol. $101864-871$.

CRISTENSEN D, CRAWFORD C and SZABO R (2002) Method MFHPB-19: Enumeration of coliforms, faecal coliforms and of $E$. coli in foods using the MPN Method. Health Products and Food Branch. Food Directorate, Health Canada, Ottawa.

DUKTA BJ and KWAN KK (1980) Bacterial die-off and stream transport studies. Water Res. 14 909-915. 
DWAF (DEPARTMENT OF WATER AFFAIRS AND FORESTRY, SOUTH AFRICA) (1996) South African Water Quality Guidelines. Volume 4. Agricultural Use: Irrigation ( $2^{\text {nd }}$ edn.). Department of Water Affairs and Forestry, Pretoria.

GEMMELL ME and SCHMIDT S (2012) Microbiological assessment of river water used for the irrigation of fresh produce in a sub-urban community in Sobantu, South Africa. Food Res. Int. 47 300-305.

GERMS W, COETZEE MS, VAN RENSBURG L and MABOETA MS (2004) A preliminary assessment of the chemical and microbial water of the Chunies river - Limpopo. Water SA 30 (2) 267-272.

GRIESEL $M$ and JAGALS P (2002) Faecal indicator organisms in the Renoster Spruit system of the Modder-Riet River catchment and implications for human users of the water. Water SA 28 227-234.

HARRIS LJ, FARBER JN, BEUCHAT L, PARISH ME, SUSLOW TV, GARRETT EH and BUSTA FF (2003) Outbreaks associated with fresh produce: incidence, growth and survival of pathogens in fresh and fresh-cut produce. Comp. Rev. Food Sci. Food Saf. 2 78-141.

KIM H, RYU JH and BEUCHAT LR (2006) Survival of Enterobacter sakazakii on fresh produce as affected by temperature, and effectiveness of sanitizers for its elimination. Int. J. Food Microbiol. 11 134-143.

KIM JB, JEONG HR, PARK YB, KIM JM and OH D (2010) Food poisoning associated with emetic-type of Bacillus cereus in Korea. Food Pathol. Dis. 7 555-563.

LÖTTER M (2010) Assessment of microbial loads present in two Western Cape rivers used for irrigation of vegetables. MSc Food Science thesis, University of Stellenbosch, Stellenbosch.

MEAD PS, SLUTSKER L, DIETZ V, McCAIG LF, BRESEE JS, SHAPIRO C, GRIFFIN PM and TAUXE RV (1999) Food-related illness and death in the United States. Emerg. Infect. Dis. 5 607-625.

MERCK (2007) Microbiology Manual (12 ${ }^{\text {th }}$ edn.). Merck KGaA, Darmstadt.

NEWELL DG, KOOPMANS M, VERHOEF L, DUIZER. E, AIDARA KANE A, SPRONG H, OPSTEEGH M, LANGELAAR M, THREFALL J, SCHEUTZ F, VAN DER GIESSEN J and KRUSE H (2010) Food-borne diseases - The challenges of 20 years ago still persist while new ones continue to emerge. Int. J. Food Microbiol. $1393-15$.

NIEMERA BA and COOKE PH (2010) Escherichia coli O157:H7 biofilm formation on Romaine lettuce and spinach leaf surfaces reduces efficacy of irradiation and sodium hypochlorite washes. J. Food Sci. 75 (5) 270-277.

OLANIRAN AO, NAICKER K and PILLAY B (2009) Antibiotic resistance profiles of Escherichia coli isolates from river sources in Durban, South Africa. Water SA 25 174-183.

PACHEPSKY Y, SHELTON DR, MCLAIN JET, PATEL J and MANDRELL DE (2011) Irrigation waters as a source of pathogenic microorganisms in produce: A review. Adv. Agron. 113 73-138.

PAULSE AN, JACKSON VA and KHAN W (2009) Comparison of microbial contamination at various sites along the Plankenburg and Diep Rivers, Western Cape, South Africa. Water SA 35 (4) 469-478.

RENTER DG, GNAD DP, SARGEANT JM and HYGNSTROM SE (2006) Prevalence and serovars of Salmonella in the feces of freeranging white-tailed deer (Odocoileus virginianus) in Nebraska. J. Wildlife Dis. 42 699-703.

SANS (2000) Method 6888-1. Microbiology of food and animal feeding stuffs: Horizontal method for the enumeration of coagulase-positive staphylococci (Staphylococcus aureus and other species). Part 1: Technique using Baird-Parker agar medium. South African Bureau of Standards, Pretoria.

SANS (2001) Method 11290-1. Microbiology of food and animal feeding stuffs: Horizontal method for the detection and enumeration of Listeria monocytogenes. Part 1: Detection method. South African Bureau of Standards, Pretoria.

SANS (2003) Method 6579. Microbiology: General guidance on the methods for the detection of Salmonella. South African Bureau of Standards, Pretoria.

SANS (2004) Method 7899-2. Water quality: Detection and enumeration of intestinal enterococci. Part 2: Membrane filter method. South African Bureau of Standards, Pretoria.

SANS (2006) Method 5667-6. Water quality - Sampling, Part 6: Guidance on sampling of rivers and streams. South African Bureau of Standards, Pretoria.

SANS (2007) Method 4833. Second Edition. Microbiology: General guidance for the enumeration of microorganisms - Colony count technique at $30^{\circ} \mathrm{C}$. South African Bureau of Standards, Pretoria.

SELA S and FALLIK E (2009) Microbial quality and safety of fresh produce. Chapter 13. In: Florkowski WJ, Shewfelt RL, Brueckner B and Prussia SE (eds.) Postharvest Handling: A Systems Approach ( $2^{\text {nd }}$ edn.). Elsevier, New York. 351-398.

SOLOMON EB and SHARMA M (2009) Microbial attachment and limitations of decontamination methodologies. Chapter 2. In: Sapers G, Solomon E and Matthews K (eds.) The Produce Contamination Problem: Causes and Solutions. Elsivier, New York. 21-45.

WARRINER K, HUBER A, NAMVAR A, FAN W and DUNFIELD K (2009) Recent advances in the microbial safety of fresh fruits and vegetables. Adv. Food Nutr. Res. 57 155-208.

WHO (1989) Health guidelines for the use of wastewater in agriculture and aquaculture. Technical Report Series No 778. WHO Press, Geneva.

WILKES G, EDGE TA, GANNON V, TOPP E and LAPEN DR (2009) Seasonal relationships among indicator bacteria, pathogenic bacteria, Cryptosporidium oocysts, Giardia cysts and hydrological indices for surface waters within an agricultural landscape. Water Res. 43 2209-2214.

WRC (WATER RESEARCH COMMISSION) (2008) WRC Knowledge Review 2007/08. Water Research Commission, Pretoria. 
http://dx.doi.org/10.4314/wsa.v39i4.3 Available on website http://www.wrc.org.za

ISSN 0378-4738 (Print) $=$ Water SA Vol. 39 No. 4 July 2013 ISSN 1816-7950 (On-line) = Water SA Vol. 39 No. 4 July 2013 